\title{
THE USE OF VISUAL TECHNOLOGIES OF EDUCATION IN ECOLOGICAL EDUCATION OF PRESCHOOL CHILDREN AS A PEDAGOGICAL PROBLEM
}

\author{
Mavluda Bakhtiyor Qizi Kubaeva \\ Master Student Navoi State Pedagogical Institute Navoi, Uzbekistan
}

\section{ABSTRACT}

The use of visual aids in the process of environmental education of preschool children is a factor of high efficiency, as they help the learner to master the learning material and then retain it in their memory and consciousness for a long time, the basis of the visual process, education the physiological mechanisms of the information presented in the form of visual images that are perceived by the recipient through vision are highlighted.

KEYWORDS:- Ecology, upbringing, education, visual, technology, child, visual, media, environment.

\section{INTRODUCTION}

Given the growing global importance of environmental problems in the world, in recent years, along with important priorities, special attention is paid to environmental protection, environmental culture, environmental education.

The urgency of environmental education is determined by the nature of our country, ecosystems, protection of the environment from instability and degradation, raising the environmental culture of the population, the need for all segments of the population, especially youth, to contribute to these very important issues.

In accordance with the Resolution of the Cabinet of Ministers of the Republic of Uzbekistan No. 434 of May 27, 2019, the Concept of
Development of Environmental Education in the Republic of Uzbekistan was adopted, which provides serious problems and shortcomings of a systematic analysis of the implementation of environmental education in the organization that hinder its implementation have been identified.

\section{THE MAIN RESULTS AND FINDINGS}

In particular:

- Insufficient requirements for environmental education provided for in Article 4 of the Law of the Republic of Uzbekistan "On Nature Protection" are not sufficiently met in all types of educational institutions;

- the current state educational standards and curricula are not adequately enriched with environmental knowledge, skills, experiences and competencies; 
- study of advanced national and foreign experience in the field of environmental education, on the basis of which no clear parameters for the formation of environmental culture in students have been developed;

- Curricula implemented at all stages of the education system are not coordinated with the essence of today's national measures aimed at overcoming global environmental problems, reducing the level of existing environmental risks, restoring the natural environment;

- The topics of educational programs of preschool and general secondary schools do not meet today's requirements, including topics related to the rational use of natural resources, the protection of ecology and the environment, the preservation of nature, which form ecological consciousness in students are insufficient;

- The system of environmental advocacy in educational institutions is also unsatisfactory, in this regard, there are insufficient measures to establish mechanisms for the implementation of environmental advocacy and appropriate incentives for these mechanisms;

- There are no clear proposals for the creation of electronic teaching aids for environmental education and expanding access to innovation;

- Insufficient practical cooperation between education and public administration in the field of ecology and environmental protection to improve the system of environmental education, in particular, the reform of the system of environmental education in recent years only suggestions on how to do it;

- There is a lack of teaching materials that provide methodological support for teachers in the field of environmental education, including textbooks on ecology and environmental protection, textbooks for students and pupils;

- Curricula need to be completely overhauled, including through radical reforms in the field of ecology and environmental protection. 1

Nature is the source of meeting the material and spiritual needs of mankind. Throughout life, man receives from nature all that he needs. Everything that man uses is a product of labour with the substance of nature.

The modern world is going through a period when environmental education and ecological culture among young people is becoming one of the most important areas of educational activity. Especially when children's environmental knowledge is formed at an early age, such education will certainly pay off. Therefore, the scientific organization of this process should be supported by the state.

In general, on the basis of a scientific understanding of the relationship between nature and society, the development of environmental education is a prerequisite for the development and application of appropriate tools and methods in the education system at the level of modern requirements. To this end, education - the harmonious development of all areas, methods and tools of education - remains relevant.

Creating a system of ecological ideology, education and upbringing plays a special role in the development of ideological education, based on the multifaceted and deep roots of our

\footnotetext{
${ }^{1}$ Ўзбекистон Республикаси Вазирлар Махкамасининг 2019 йил 27 майдаги 434-сон қарорига асосан Ўзбекистон Республикасида Экологик таълимни ривожлантириш Концепцияси
} 
CURRENT RESEARCH JOURNAL OF PEDAGOGICS 2(6): 06-10, June 2021

DOI: https://doi.org/10.37547/pedagogics-crjp-02-06-02

ISSN 2767-3278

(C)2021 Master Journals

\section{Crossref do) 81 Google}

Accepted 04th June, 2021 \& Published 09th June, 2021

national spirituality.

Extensive use of all effective forms and methods of cultural and educational work, including: mass media, oral, visual and technical means, as well as the provision of theoretical environmental knowledge in the formation of ecological consciousness, ecological education, ecological culture in preschool children it is expedient because environmental advocacy should not only affect the minds of certain categories of the population, but should cover all segments of the population, from kindergarten age children, and should be understandable, visible and transparent to all. By informing about nature, land, water, flora and fauna, natural resources, the younger generation should play the role of environmental education cradle in the minds of the younger generation to respect nature and use natural resources wisely.

Providing children from an early age with knowledge about man and nature, their interaction and harmony - is an important task of the educational process in preschool education today.

Observations show that the theoretical concepts of ecology as a system of knowledge for adults and children and the basics of their use, that is, the need to reflect the new content of acquainting preschool children with nature on the basis of an ecological approach.

The dual function of theoretical data can be seen in this:

- formation of scientific knowledge of ecology of the organizations of preschool education, educators;

- Development of a system for the formation of environmental knowledge for students.

At the same time, it is important to determine which of the environmental concepts is important and can form the basis of the ecological education system.
What is ecology in general and what is reflected in its analysis?

Ecology is interpreted as the study of the relationship between organisms and the environment ${ }^{2}$.

Ecology is divided into general and specific ecology according to the objects studied.

General ecology is the study of the structure and function of various systems above the body. It consists of sections such as population ecology, biocenology, and ecosystem ecology. Population ecology is the study of the general laws of population structure and quantitative dynamics, as well as the interactions (competition, predation) between populations of different species. Biocenology (community ecology) studies the laws, structure, and function of biocenoses.

Specific ecology is the study of a set of relationships between organisms belonging to a particular taxonomic group to environmental conditions (eg, insect ecology). Private ecology is sometimes viewed as a science that studies a particular ecosystem and community. ${ }^{3}$

Given the unique characteristics of children's age, their mental and personal development, the departments of biological ecology at different levels in the upbringing of preschool children can serve as a scientific basis for the creation of sufficient knowledge and methods.

There are two criteria for selecting and understanding environmental fact materials:

- visual exhibitions;

- examples of practical activities that can be introduced to children.

https://ru.wikipedia.org/wiki/\%D0\%AD\%D0\%BA\%D0\%BE\%D0 \%BB\%D0\%BE\%D0\%B3\%D0\%B8\%D1\%8F

${ }^{3}$ https://qomus.info/encyclopedia/cat-e/ekologiya-uz/ 
CURRENT RESEARCH JOURNAL OF PEDAGOGICS 2(6): 06-10, June 2021

DOI: https://doi.org/10.37547/pedagogics-crjp-02-06-02

ISSN 2767-3278

(C)2021 Master Journals

\section{Crossref do) 81 Google}

Accepted 04 th June, 2021 \& Published 09' ${ }^{\text {th }}$ June, 2021

One of the most effective methods for preschool children is autecology. In doing so, children are surrounded by clear, isolated living organisms. Plants, indoor and outdoor plants that grow indoors and outdoors (at home, in the garden), domestic and decorative animals, birds and insects can have an environmental impact on a child.

In the research work of N.S. Nikolaeva, "The organism and the environment are a single natural complex, in which the physiological and morphofunctional properties of the organism serve as the key to a clear understanding of the environment. Acquaintance with any specific organism (whether plant or animal) takes place only through the environment in which it lives. $\mathbf{4}$

In preschool, only visually effective and visually figurative forms of thinking are used that enable the understanding and assimilation of specially selected and age-appropriate information about nature.

The word "visual" is derived from Latin and means "visualis", which means can be seen.

Visuality is the general name for the methods of seeing, observing, and analyzing digital information or a physical phenomenon.

A. A. Verbitsky expressed the following views on visualization: "The process of visualization is a shortening of the process of thinking in the visual image, and the perceived image can serve as an aid to broad thinking and practical actions." 6 This definition allows us to distinguish between the concepts of "visual", and "visual aids".

As a pedagogical concept, the concept of "visual" is based not on a person's innate plan, but on the

\footnotetext{
4

${ }^{5}$ https://ru.wikipedia.org/wiki

${ }^{6}$ Вербицкий А. А. Активное обучение в высшей школе: контекстный подход. М.: Высш. шк., 1991. 207 с.
}

presentation of specific objects, processes, events, and the presentation of a complete image, which is always given from the outside. It demonstrates the development of the mental image in the production of the image of thoughts, that is, in the "bringing" from the inside to the outside. This precession is built on the interaction of the subject and objects of the material world, which relies on the mechanisms of thinking and is manifested in various forms of educational activity. ${ }^{7}$ [2, p. Verbitskiy].

\section{Conclusion}

Thus, A. A. Verbitsky explained the concepts of "showing display" and "visual" in pedagogy. The main difference between them is that the exhibition medium is an object that represents a certain image, and the visual medium is a product of human mental activity, and a guaranteed end result is obtained.

According to A.P. Malkina, "increasing the internal activity of the receiver allows for semantic perception of visual aids (drawings, diagrams, tables, pictures, photographs, etc.) and data processing."

The use of visual aids in the learning process is a factor of high efficiency, as they help the learner to master the learning material and then retain it in their memory and consciousness for a long time. The basis of the visual process is the physiological mechanisms of information presented in the form of visual images that are perceived by the learner visually.

\section{REFERENCES}

1. Resolution of the Cabinet of Ministers of the Republic of Uzbekistan dated May 7, 2019 No

\footnotetext{
${ }^{7}$ Вербицкий А. А. Активное обучение в высшей школе: контекстный подход. М.: Высш. шк., 1991. 207 с
} 
CURRENT RESEARCH JOURNAL OF PEDAGOGICS 2(6): 06-10, June 2021

DOI: https://doi.org/10.37547/pedagogics-crjp-02-06-02

ISSN 2767-3278

(C)2021 Master Journals

Crossref dof 81 Google

Accepted 04thJune, 2021 \& Published 09th June, 2021

434 "On approval of the Concept of development of environmental education in the Republic of Uzbekistan".

2. To the Ministry of Preschool Education of the Republic of Uzbekistan "The state requirements to development of the first and preschool children of the Republic of Uzbekistan". Tashkent, June 18, 2018 Order No. $1 \mathrm{mh}$.

3. State Curriculum "First Step" of the Ministry of Preschool Education of the Republic of Uzbekistan. Tashkent, July 7, 2018, Life Resolution No. 4.

4. Namatov A.N. Ecology / Glossary of key terms and phrases. - $\mathrm{T}$.: Bioekosan Publishing House, 2001.

5. Tokhtaev A.S. Textbook for students of ecological / pedagogical institutes. - T.: "Teacher" Publishing House, 2001. 